\title{
The Relevance of E-Commerce Tax Application in Indonesia: Based on the Perspective of Taxation Expert
}

\author{
Authors: \\ Gandy Wahyu Maulana Zulma ${ }^{1}$ \\ Achmad Hizazi ${ }^{2}$ \\ Affiliation: \\ ${ }^{1,2}$ Department of Accounting, \\ Faculty of Economics and \\ Business, Universitas Jambi \\ Corresponding Author: \\ Achmad Hizazi \\ Emails: \\ 'hizazi@gmail.com \\ ${ }^{2}$ maulanagandi25@unja.ac.id \\ Article History: \\ Received: August 31, 2020 \\ Revised : November 28, 2020 \\ Accepted: December 6, 2020 \\ How to cite this article: \\ Zulma, G. W. M. \& Hizazi, A. \\ (2020). The Relevance of E- \\ Commerce Tax Application in \\ Indonesia: Based on the \\ Perspective of Taxation Expert. \\ Organum: Jurnal Saintifik \\ Manajemen dan Akuntansi, \\ 3(2), 94-108. doi: \\ https://doi.org/10.35138/organu \\ m.v3i2.103
}

Journal Homepage: ejournal.winayamukti.ac.id/ind ex.php/Organum

Copyright:

(c) 2020. Published by Organum: Jurnal Saintifik Manajemen dan Akuntansi Faculty of Economics and Business. Winaya Mukti University.
Abstract. This study aims to understand the relevance of $e$ commerce tax regulations in Indonesia, which were cancelled by the Government. The method used is applied research with explorative study techniques designed in structured questionnaires and interviews with 15 respondents who were judged to have the right expertise with different backgrounds such as consultants, tax observers, academics, managers, e-commerce entrepreneurs, and policymakers. The results showed that it was necessary to revise tax laws to adjust to the digital era's demands soon. In addition, technological innovation in taxation was considered to reduce administrative costs in terms of tax authorities. Big Data tax management was considered to make tax authorities' performance efficient and can anticipate higher costs. The quality of human resources must support technological innovation to bring up a new profession in the future, namely experts who master tax and technology with the term "Taxologist". Finally, the Government needs to secure ValueAdded Tax (VAT) taxes in the short term until a global consensus agreement is reached in 2020.

Keywords: E-commerce taxation; relevance; expert's perspective.

Abstrak. Penelitian ini bertujuan untuk mengetahui relevansi regulasi pajak e-commerce di Indonesia yang sempat dibatalkan oleh Pemerintah. Metode yang digunakan adalah penelitian terapan dengan teknik studi eksploratif yang dirancang dalam kuesioner terstruktur dan wawancara dengan 15 responden yang dinilai memiliki keahlian yang tepat dengan latar belakang yang berbeda seperti konsultan, pemerhati pajak, akademisi, manajer, pengusaha e-commerce, dan pembuat kebijakan. Hasil penelitian menunjukkan bahwa undang-undang perpajakan perlu direvisi untuk segera menyesuaikan dengan tuntutan era digital. Selain itu, inovasi teknologi di bidang perpajakan dinilai dapat menekan biaya administrasi dari segi otoritas perpajakan. Pengelolaan pajak berbasis Big Data dinilai dapat mengefisienkan kinerja otoritas pajak dan dapat mengantisipasi biaya yang lebih tinggi. Inovasi teknologi harus didukung oleh kualitas sumber daya manusia dan dapat memunculkan profesi baru di masa depan yaitu tenaga ahli yang menguasai perpajakan dan teknologi dengan istilah "Taxologist". Terakhir, pemerintah perlu mengamankan pajak PPN dalam jangka pendek hingga kesepakatan konsensus global tercapai pada tahun 2020.

Kata Kunci: Pajak e-commerce; relevansi; perspektif ahli.

\section{Introduction}

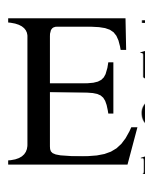
-commerce continues to grow and become a giant business model in a new era. Research conducted by Google and Temasek shows that the e-commerce market value in Southeast Asia in 2017 reaches around 
US \$1 billion, and this number is predicted to continue to increase to US \$ 88 billion by 2025. Huge potential, especially for tax revenues in Indonesia, has more than half of e-commerce market share users in Southeast Asia.

The issue of e-commerce is a hot topic to be discussed right now in Indonesia. Since the Government issued tax regulations for e-commerce marketplaces in PMK No.210/PMK.010/2018 regarding the tax treatment of trade transactions through electronic systems, various concerns have arisen in the community, especially for online businesses. The main challenge in e-commerce tax enforcement is applying existing tax laws into the principles of ecommerce transactions that are unique compared to conventional trade (Oguttu \& Tladi, 2009).

E-commerce rejects the stigma that every form of business must have a permanent residence and eliminate geographical restrictions because transactions can occur between countries and even continents that exist throughout the world (Mann et al., 2000). It certainly creates difficulties for tax authorities to identify where businesses are located and where their sources of income are due to the use of domains and internet service providers in e-commerce, making it even more difficult to detect through general tax principles.

Conventional tax regulations are increasingly irrelevant as a basis for ecommerce taxation (Omar et al., 2009; Agrawal \& Fox, 2017). Meanwhile, according to Setiawan (2018), the traditional trade sector has switched to electronic commerce and has an impact on reducing tax revenues in Indonesia. The Indonesian Government's move to issue the latest regulations regarding ecommerce taxes is the right decision; however, there is still debate about the regulations' relevance and effectiveness.

Besides, issues related to tax rates, subjects, collectors, and objects taxed in e-commerce transactions are still being debated globally. According to Bird (2003), some tax experts consider that ecommerce transactions should not be taxed, they should even be given subsidies to continue growing. Nevertheless, other experts consider this a promising opportunity and are expected to take advantage of the rise of digital commerce.

Smith (2007) states that tax experts are aware of the tax rules in most countries designed when e-commerce has not yet existed, so the current tax rules are considered ineffective in capturing this phenomenon. Besides, concerns regarding the application of e-commerce tax rules can harm the State if not supported by adequate regulations (Jones $\&$ Basu, 2002). The problem of ecommerce taxation can be a challenge for most tax regulators globally, including Indonesia, facing these problems.

Based on the problems, it is crucial to research the impact of e-commerce tax regulations' enactment based on practical and theoretical experience to find the right solution. Therefore, this study intends to explore the concept of ecommerce taxation more deeply by Indonesia's characteristics by involving experts.

\section{Literature Review}

\section{Global Debate Regarding E-Commerce Taxation}

The digital economy's development had created new challenges for taxation systems in various countries (Cockfield, 2001). This problem occurs because the current taxation system is designed to collect taxes from conventional industries. While under current conditions, the business challenges faced are entirely different.

Based on the study results, two fundamental issues pose a significant 
challenge for re-forming conventional taxation schemes. First, the goods traded are "intangible", and second are "crossborder" for examples such as transaction services for movies or songs and software or intangible application trading.

Besides, problems related to digital companies' physical presence where companies do not need to build representative offices or move factories if they want to do business in a country make current taxation regulations irrelevant (Weber \& van Weeghel, 2011). Because of the old rules' limitations, it is effortless for e-commerce companies to avoid tax regulations and move their profits to tax haven countries.

To solve this problem, OECD (Organization for Economic Co-operation and Development) designed a guideline relating to applying the concept of "Permanent Establishment" in the context of e-commerce taxation (OECD, 2013). This guideline guides determining whether a website or server qualifies as a permanent establishment recognition. However, this problem will raise the next question that needs to be answered: Who can be made a digital tax cut? Moreover, how is the mechanism for cutting its taxable income?

\section{Fundamental Challenges of E- Commerce in Indonesia}

According to Laudon \& Traver (2017), there are fundamental challenges that arise from e-commerce, namely their characteristics that can be done anywhere and anytime. These characteristics distinguish e-commerce from conventional trade, which refers to the necessity to have a place or physical presence if one wants to make a transaction, but in e-commerce, in general, there is not necessarily a physical form even in a country that is the target market. It is undoubtedly a regulatory challenge in the future to impose taxes as they should without making taxpayers burdened with multiple tax expenses.
Furthermore, the imposition of VAT tax on transactions certainly requires evidence or data that the transaction happened. Because sales are carried out through an extensive internet network, of course, it is difficult to detect data of any transactions that have occurred. Besides, e-commerce businesses can quickly delete information or provide incorrect data related to their transaction history. This challenge certainly puts the Government at a disadvantage, especially regarding the technology's readiness and the quality of the resources now, whether it is sufficient to overcome the problem.

The current tax-based regulation model tends to require taxpayers' physical presence that might be difficult to find in the e-commerce business model. So the problem certainly makes it difficult for the Government to tax ecommerce. No exception in Indonesia, some time ago, the Government spontaneously withdrew e-commerce tax regulations issued because of causing controversy in Indonesian society. It raises a big question of what is wrong with the e-commerce tax, which was suddenly canceled even though it had just been published.

\section{Theory Basis for Designing more Relevant Tax Regulations}

Adam Smith's theory in his book The Wealth of Nations (Smith, 2010), citizens will be willing to pay taxes if the tax collection system meets the four principles of tax collection, or what is also known as "The Four Maxims", as follows:

1) Equality principle (the principle of balance with ability or principle of justice), namely tax collection carried out by the state, must be following the Taxpayers' ability and income. The state may not act discriminatively against taxpayers;

2) The principle of certainty (the principle of legal certainty), namely that all tax collections must be based 
on law, so that those who violate will be subject to legal sanctions;

3) The convenience of payment (timely tax collection or pleasure), which means that tax must be collected at the right time for the Taxpayer (the best time), for example, when the Taxpayer receives their income or when the Taxpayer receives a gift; and

4) Efficiency principle (efficient principle or economic principle), namely that the cost of collecting taxes is made as economical as possible so that the cost of collecting taxes is not greater than the result of tax collection.

Based on the above theory, this research seeks to design ten basic questions that need to be given to taxation experts in Indonesia to become input for regulators in preparing better ecommerce tax regulations in the future.

\section{Research Method}

\section{Research Design}

This research is applied research with exploratory study techniques. According to Sekaran \& Bougie (2016), explorative studies are conducted when much is unknown about the situation that will occur, or no information is available about how research problems or problems are almost the same are resolved beforehand. Techniques that are designed by the problem to be solved, given the focus of research, also have the characteristics of limited information regarding e-commerce tax rules. The research uses field study techniques by using a questionnaire and a structured interview method.

\section{Sample and Population}

The sampling method uses purposive sampling with certain types of considerations (judgment sampling). In such cases, researchers can reduce the generalisation of findings because sampling methods allow obtaining the kind of information needed from a particular group of people and only those who have the facts needed and can provide the information sought as related to this research regarding the relevance of the application e-commerce tax in Indonesia.

Based on Table 1, this research obtained a sample of 15 respondents consisting of different backgrounds such as consultants, tax observers, academics in the field of taxation, managers/heads of corporate tax, representatives of ecommerce experts, and regulators who set tax regulations for e-commerce in Indonesia. It is done to obtain a valid data source so that adequate conclusions can be drawn regarding e-commerce tax implementation's relevance in the future.

\section{Data Collection Method}

In the implementation of data collection, each respondent was asked to fill out a questionnaire with closed questions and then interviewed with open questions to dig more in-depth information. After that, interviews were conducted directly by recording the sound of each statement given by the respondent. The recording results are then heard repeatedly and made into a conversation script to record information clearly. In this activity, researchers used technical assisted research assistants to convert audio to text and were supervised and repeatedly checked regarding the compatibility between sound and text written from the interview content that had been conducted. It aims to maintain content validity.

According to Sekaran \& Bougie (2016), content validity is carried out to ensure that measurements include a sufficient set of points and represent the concepts that are the focus of research. The more scale points represent the area or range of theories being measured, the higher the content validity. So, it can be said that content validity is a function of 
how well the dimensions and elements are described in a research concept.

\section{Result and Discussion}

\section{Top 10 Questions and Answers Based on Tax Experts in Indonesia}

\section{Is It Urgent or Not to Revise the Tax Regulation Immediately?}

The first statement, the focus of the problem regarding the need for revision of taxation rules following the digital era's development to provide certainty to business people, was strongly supported by respondents. Table 2 shows statistics of $66.7 \%(n=10)$ respondents felt strongly agree with the statement and the remaining $33.3 \%(n=5)$ felt agreed. In the context of digital e-commerce problems, taxpayers, without exception, of course, expect certainty of regulation, especially regarding how the taxation aspects they have to follow.

According to respondents (1, 3, and $4)$, one of the crucial issues in ecommerce taxation is the unclear definition of a permanent establishment, especially for permanent foreign establishments. It can cause transactions related to foreign countries not to be taxed by the State. Respondents (2, 5, and 6) argue that it cannot be denied that the unique nature of digital business does not know the limits and time; every actor can carry out transactions from anywhere and at any time, which makes the technical rules of digital taxation increasingly complex. Besides, transactions relating to e-commerce at this time can indeed be said to be impressed as not well regulated regarding the technical rules of tax, so the impact of regulations regarding ecommerce cannot be enforced as a whole (Hanefah et al., 2008).

Most tax experts are quite disappointed with the repeal of Minister of Finance Regulation Number 210 regarding the taxation treatment of trade transactions through electronic systems (e-commerce). Respondents (1 and 3) feel that the e-commerce tax regulations do not need special treatment, such as the need not to impose new tariffs on both the subject and the object. However, it would be better if the revised ecommerce tax regulation should instead focus more on the context of how to solve problems regarding the definitions of permanent establishment definition, tax registration number, Taxable Enterprise(s) definition, seeking fair and transparent administrative arrangements for taxpayers, and supervision related to fulfilling e-commerce taxation rights and obligations.

\section{Does Digitalisation Change the Behaviour and Business Regulations Today?}

In the second statement, digitalisation changes business behaviour and has an impact on tax rules that vary from country to country. Table 2 shows that $53.3 \%$ of respondents $(n=8)$ felt strongly agree and some respondents felt agree with a percentage of $46.7 \%(n=7)$. It is undeniable that the digital era's development is so massive that today's business models have also changed. Respondents (2, 4, and 6) argue that the digital economy has changed the business sector, where the dependence on users and Big Data intersects with intangible activities that cause economic disruption in Indonesia and globally. So, this change will certainly also change regulations in various countries. According to Respondents (3 and 5), the change was addressed in different ways in each country, and there were active and some passive countries.

According to Respondents (1), since the launch of the BEPS (Base Erosion and Profit Shifting) project by the OECD through the final report on "Digital Economy", it seems that pessimism has arisen in each country regarding digital tax consensus so that these countries are trying to formulate themselves - own policies on digital taxation such as the UK which decided to 
implement "Google Tax", India adopted another type of levy outside income tax $(\mathrm{PPh})$ under the name "Equalisation Levy" (EQL), Israel issued a new policy related to the definition Permanent Establishments. At the same time, other countries such as Cuba and Uganda apply social media taxes. Countries in the world take strategies to fill the vacuum of digital tax regulations that have not been agreed on globally.

More interestingly, in contrast to the conditions in the United Kingdom (UK), the United States (US) as a Superpower in the world, carried out tax reforms in depth by taking policies through a new law known as the "Tax Cuts and Jobs Act (TCJA)" which effective since 2018 which is the beginning of an overhaul of the US tax scheme 30 years ago that have never made changes to tax regulations. Respondents (2 and 3) argue that there are some exciting things in the new US law where there is a change in the tax system from "worldwide" to the "territorial" tax system.

It is no secret that the US is the only G7 member country that implements the "worldwide" system. Besides that, the US is also 8 of 34 OECD countries that adhere to the "worldwide" system. However, in the digital era, as it is today, the US's policy was previously considered to be uncompetitive and tends to place the US in an unfavourable position in global competition.

Based on the Wealth of Nations theory coined by Adam Smith (Smith, 2010), four principles should be owned by a country's taxation system: equality, legal certainty, convenience, and efficiency (Downer, 2001). It is not owned by the "worldwide" tax system, which causes the US to fail to fulfil these principles because this system is considered unequal, unclear, complicated, and inefficient. Respondents $(1,2$, and 3$)$ argue that different from the "worldwide" mode, the "territorial" policy is seen as more flexible so that it can better solve problems faced by most countries such as certainty, ease, and high compliance costs in the digital economy era. Indonesia currently adheres to the "worldwide" system, which is the same as the old US system, so changing the policy to "territorial" can be a good alternative for Indonesia.

\section{Creating Special Provisions Rather than Changing the General Rules?}

In the third statement, Indonesia should make specific provisions on ecommerce rather than changing the general tax rules. Can be seen in Table 2 shows that $53.3 \%$ of respondents $(n=8)$ felt strongly agree. Some respondents felt they disagree with a percentage of $26.7 \%$ $(\mathrm{n}=4)$, while the rest were neutral, with a percentage of $20 \%(n=3)$. There are pros and cons to changing the general rules to overcome the problems that arise in the digital economy era.

Agrawal \& Fox (2017) stated that several European Union countries, including the US, have responded to the development of the e-commerce business by adjusting tax regulations that are more adaptable to current business developments. Some respondents agreed to make special income tax provisions on large businesses conducted by companies such as Google, Facebook, YouTube, Instagram, Amazon, Spotify, and Zoom in Indonesia.

Respondents (5 and 6) considered that it was undeniable that many of these giant digital companies were utilising consumers (users) and controlling the digital market in the area of Indonesia but did not establish anything in Indonesia. While respondents (1 and 3) see that in general, it can be said that there is nothing wrong with domestic rules that have been applied up to now, but when we discuss cross-border transactions, it is necessary to apply special rules to impose taxes on foreign companies which are not Permanent Establishment (PE) in Indonesia. 
Respondents (1, 3, and 6) argue that domestic regulation does not need much change but needs a particular strategy to counter e-commerce by issuing special provisions. Respondents (1, 4, and 5) offer an alternative solution for the Government to make short-term decisions in advances such as a focus on the imposition of Value-Added Tax (VAT), which is considered more realistic to be implemented rather than collecting income tax on digital ecommerce companies where Indonesia still has difficulties in getting data access and tax base.

Respondents (1, 3, and 6) argue that domestic regulation does not need much change but requires an exclusive strategy to counter e-commerce by issuing special provisions. Respondents (1, 4, and 5) offer an alternative solution for the Government to make short-term decisions in advances such as a focus on the imposition of Value-Added Tax (VAT), which is considered more realistic to be implemented rather than collecting income tax on digital ecommerce companies where Indonesia still has difficulties in getting data access and tax base.

\section{The Current System Cannot Provide Justice?}

In the fourth statement, the current taxation system does not guarantee fair tax payments to digital businesses, especially across countries. Can be seen in Table 2 shows that $66.7 \%$ of respondents $(\mathrm{n}=10)$ felt strongly agree, and some respondents felt agree with a percentage of $33.3 \% \quad(\mathrm{n}=5)$. Respondents (1,3, and 6) argue that the application of taxes for digital companies is an effort to create economic justice. If a country cannot make it happen, it will undoubtedly lead to conflict and reduce the tax compliance that has been built so far.

The emergence of global ecommerce has been a challenge for tax authorities, which is also a major concern in many jurisdictions. E-commerce has disturbed the smooth running of tax rules and regulations designed by tax authorities (Horn, 2003). However, the Government must immediately decide to enforce justice through effective tax regulations for all Indonesia businesses.

Respondents (2, 4, and 5) provide alternative solutions that the Government must immediately take concrete steps in solving digital tax problems. Regulations regarding e-commerce tax or broader than the previous rules must be issued directly, besides that the Government needs to create an integrated system that can monitor every transaction that occurs digitally and regulate the exclusive collection in detail.

\section{What Can E-Commerce Businesses Do to Trigger Tax Avoidance?}

In the fifth statement, e-commerce has the potential to create a higher risk of tax avoidance, especially for cross-border business transactions. It can be seen in Table 2, which shows that $66.7 \%$ of respondents $(n=10)$ felt agree, and the rest felt strongly agree with a percentage of $33.3 \%(\mathrm{n}=5)$. Overall, it can be said that respondents agreed that e-commerce has a higher risk of tax avoidance, especially for cross-country transactions that often occur in the digital economy era.

According to Respondents (1, 3, and 5), the presence of e-commerce increases the chances of a "Base Erosion and Profit Shifting (BEPS)". This problem is undoubtedly a complicated issue, especially regarding policies related to Permanent Establishments (PE), which are still based on the physical presence that has been echoed by the countries which are members of the OECD. It seems that it can no longer be used to deal with digital business models.

Respondents (2, 4, and 6) argue that e-commerce issues are, of course, very different in dealing with domestic taxes, tax problems in the local context can be 
resolved with existing domestic provisions, but this will be different when dealing with digital companies, the State will certainly have to compromise with outside countries, in the sense that there must be an agreement both bilaterally and unilaterally regarding tax sharing internationally.

Respondents (2, 3, and 5) see that the administration and digital data issues are obstacles in realising tax compliance for e-commerce actors. Respondents (1, 5 , and 6) see that digital companies can freely report their taxes as much as they want and will not even pay the slightest if there is no access to obtain their data to be used as a basis for taxation. Conditions like this are certainly very terrible and should not continue to happen.

In an era that uses computers and the internet, of course, it should be more open to information, every second of the events that occur online are certainly well recorded. Respondents (2, 4, and 6) support the Government's efforts to create a new system that can record information about every digital transaction that takes place in Indonesia, and establish a digital platform and social media as Taxable Entrepreneurs and are required to become tax collectors for each user involved in their business. Besides, Respondents (1, 3, and 5) recommend that proper socialisation, education, and tax authorities' supervision are also necessary for ecommerce actors.

Othman, Z., \& Hanefah, M. M. (2006) revealed results similar to previous studies that e-commerce will lead to double taxation, tax loss, lower physical experiences, and tax avoidance. The findings also indicate that the basis for determining a permanent establishment for e-commerce taxation needs to be studied further in assisting ecommerce in Malaysia. Therefore, it is necessary to make adjustments to tax regulations by the Government to limit the risk of massive tax avoidance in electronic commerce.

\section{Uncertainty in E-Commerce Regulations Need to Be Resolved Globally?}

In the sixth statement, resolving the polemic of the uncertainty of e-commerce tax regulations needs to be supported by changes internationally. It can be seen in Table 2, which shows that $73.3 \%$ of respondents $(\mathrm{n}=11)$ felt strongly agree, and the rest felt agreed with a percentage of $26.7 \%(n=4)$. Overall, it can be said that respondents agreed that regulations regarding e-commerce could not be resolved locally, Indonesia needs to collaborate with foreign countries as has been done now, namely joining the G20 states to discuss global issues, especially regarding the problems of each country in the digital age.

Zulma et al. (2019) stated that taxation policy must focus on fair and firm law enforcement, conduct measured and systematic audits, provide services and socialize policies to the public and facilitate all tax administration matters. So that the better the Government treats taxpayers, the higher the motivation of taxpayers to comply.

Respondents (2, 3, and 4) argue that concrete steps taken while waiting for global consensus, namely through the BEPS Inclusive Framework Project, which consists of 129 countries in the world, can be an e-commerce tax solution. In the Project, the focus is on rights and profit allocation schemes and anti-tax avoidance schemes known as "Global Anti-Base Erosion (GloBe)". In regulating the rights scheme and the allocation of profits is regulated regarding the source country's right to collect taxes on e-commerce companies even without a presence in the country.

Respondents (1, 5, and 6) believe that the need to change the Permanent Establishment criteria is not based on physical presence because it is not profitable for a source of income such as 
Indonesia. Besides, the allocation of digital company profits should favour income countries' source regarding sales or the number of users in the source country. Moreover, the agreement related to the minimum tax that must be received by the source country will be able to benefit developing countries like Indonesia, because in addition to the profit-sharing obtained, of course, it can also reduce pressure on states to lower tax rates.

\section{Is the Implementation of $\mathbf{E}$ - Commerce Tax Delayed Due to the Limited Quality of Human Resources and Technology?}

Table 2 shows that $66.7 \%$ of respondents $(\mathrm{n}=10)$ feel strongly agree, $13.3 \%$ of respondents $(n=2)$ feel agree, $6.7 \%$ of respondents $(n=1)$ disagree and the rest are neutral with a percentage of $6.7 \%(\mathrm{n}=1)$. There are pros and cons related to respondents' opinions about the limitations of technology and human resources quality, including Indonesia's problems in re-solving e-commerce taxes. Respondents (1, 4, and 6) argue that in the digital age, technology and the quality of human resources can certainly be the key to a country's success facing changes in current business conditions.

Respondents (2, 3, and 5) see that Indonesia needs to invest heavily in building digital infrastructure and improving qualified human resources quality. The quality of the tax officer human resources is still considered inadequate in terms of technological mastery. Indeed, it is expected that those who fill tax positions need a new profession in the future, namely "Taxologist", meaning that future HR tax qualifications need to demand mastery of taxes and technology that cannot be separated.

Recently, Indonesia's shadow economy is estimated to reach $26.6 \%$ of the Gross Domestic Product (GDP) from 2005 to 2015 (Medina \& Schneider, 2018). It shows that there are still many e-commerce activities that have not been detected by the tax authority; technological support is vital in reaching out to the digital economy players. Respondents (2 and 4) argue that technological innovation has become an integral part of the current taxation system. Not only limited to the purpose of tax optimisation, but the use of technology also needs to be encouraged to realise a tax administration that is practical, fast, and effective, and oriented towards service to taxpayers.

According to respondents (1, 4, and $6)$, technological innovation in taxation can undoubtedly reduce tax administration costs. Big Data management is considered to make tax authorities' performance efficient and prevent higher prices from happening early. The quality of competent human resources must support this technology's development because they are the operators who run the existing systems and procedures. So that if the limitations of technology and human resource problems can be appropriately resolved, it will benefit Indonesia in facing the digital era's challenges.

\section{Can the Certainty of E-Commerce Regulation Improve Tax Compliance?}

In the eighth statement, ecommerce tax regulations can provide certainty of time and transparency in tax administration to affect tax compliance. Table 2 shows that $53.3 \%$ of respondents $(\mathrm{n}=8)$ felt strongly agree, and the rest felt agreed with a percentage of $46.7 \%$ (n $=7$ ). Overall, it can be said that respondents agreed that the need for legal certainty related to e-commerce taxes for the sake of creating transparency and timeliness in tax administration so that taxpayers can be more confident with the Government that will foster compliance in paying taxes.

Zulma (2020) stated that knowledge of taxation, tax administration, and tax sanctions positively affect taxation in 
Indonesia. Increasing the level of knowledge of taxation, tax administration, and law enforcement that is fair and transparent can improve tax compliance. The Government needs to regulate tax administration to increase tax revenue in Indonesia. According to Respondents (1, 3, and 4), Indonesia currently has an anti-abuse legal issued in the Regulation of the Director-General of Tax PER-25/PJ/2018. However, when talking about international regulations, of course, there must be an agreement between countries that must be negotiated so that Indonesia's domestic tax regulations may not be fully applicable. The absence of a global consensus that was mutually agreed on seems very detrimental to user base source countries (Users) such as Indonesia, China, and India, which do not get a fair tax from giant digital companies.

In filling the regulatory vacuum before the global consensus was agreed upon in 2020. according to respondents (2, 5, and 6), the Government should continue to decide to issue new tax regulations on e-commerce taxation, such as the imposition of Value-Added Tax (VAT) on digital companies, which is easier to implement than income tax, while respondents $(3,4$, and 5$)$ see that in the long run, the Government must continue to look for ways to get income tax from digital companies that are considered to have a much higher value than the VAT.

Setiawan (2018) states that changes in tax regulations to the imposition of VAT on the e-commerce business can provide benefits for Indonesia. The potential tax value in 2017 is almost around IDR 15.14 trillion and in 2018 around IDR 16.64 trillion, with the potential value of VAT contributing around $90 \%$ of the total potential tax revenue from the Indonesian e-commerce sector.

\section{Can AEol Implementation Improve Tax Implementation?}

Table 2 shows that $53.3 \%$ of respondents $(\mathrm{n}=8)$ felt strongly agree, and the rest felt agreed with a percentage of $46.7 \%(n=7)$. Overall, it can be said that respondents agreed that the implementation of AEol (Automatic Exchange of Information) would undoubtedly make taxpayer information more open, especially for digital transaction actors, so that it is expected to increase taxpayer compliance further. In Tax Regulation Number 9 Year 2017, it has been determined that data must be reported and exchanged regarding taxpayers, such as the identity of the account holder, account number, balance, and income related to financial accounts that can be obtained automatically through AEoI.

Zulma et al. (2019) stated that the tax reforms carried out are expected to build conditions in which tax institutions become stronger, more credible, and accountable, which have effective and efficient business processes. Tax administration reforms have certainly played an important role; tax administration changes must be carried out by considering economic conditions both domestically and internationally.

According to Respondents $(1,3,5)$, in the 2018 Directorate General of Tax reports, Indonesia is currently implementing AEoI of 5,870 registered financial institutions and accessing about 2000 financial information reports obtained from banks, capital markets, and insurance companies. It certainly shows the starting point of the era of transparency in the tax sector in Indonesia. According to respondents (2, 4, and 6) shows that currently, the Government has begun to invest in designing a Core Tax Administration System (SIAP), which was adopted from a country that has proven successful in implementing a tax administration system named "Core Tax System". This system 
is designed to integrate data and needs both in terms of tax authorities and taxpayers. For tax authorities through this system can analyse the risk and decision making for any potential tax avoidance. As for taxpayers, this system can provide ease of service, assistance, and solutions needed by taxpayers.

According to Respondents (2, 3, and 5), optimising the role of AEol needs data that is integrated with business processes and tax administration such as the identity of taxpayers, online administration processes, payment processes using the system, the system is connected with the company's accounting process, able to group revenues by type tax, regional and revenue periods and confidentiality is maintained. Respondents (2 and 5) considered that if the core tax system that was designed could answer these conditional, inevitably, a better tax compliance condition would be created than it is today, especially in controlling ecommerce tax.

\section{Is it Necessary to Change the Permanent Establishment Definition?}

In the final statement, the Government needs to set more explicit terms regarding the determination of the Permanent Establishment (PE), considering that the business model of ecommerce companies does not use physical presence to keep attracting profits from a country. It can be seen in Table 2 that shows that $66.7 \%$ of respondents $(\mathrm{n}=10)$ felt strongly agree, and the rest felt accepted with a percentage of $33.3 \%(n=5)$. Overall, it can be said that respondents agreed that the Government needs to change the definitions of PE, which are considered to be no longer suitable to be applied in the digital economy era in which business activities generally no longer have to have a physical presence.

According to Respondents (1, 5, and 6), in dealing with the digital business model that is happening right now, it is undoubtedly necessary to revise the existing definitions of permanent establishment. Besides, in a broader context, the Permanent Establishment's actual meaning does not focus on digital companies and needs to anticipate new business models of well-known companies that may not be digital but succeed in avoiding taxes in Indonesia. Respondents (1, 3, and 4) consider that The Permanent Establishment definition is a form of legal certainty that can be given by the Government to foreign taxpayers, especially those who obtain economic benefits in Indonesia.

According to the respondent $(2,3$, and 5), the Permanent Establishment definitions do not need to be removed entirely but only need to add points to reinforce the Permanent Establishment according to the current conditions. The basic concept of Permanent Establishment is a form of business that is used by both individuals and foreign bodies that carry out activities in Indonesia with the permanent or nonpermanent place of business, as long as there are indications in terms of actions to obtain, collect or maintain income originating from Indonesia, of course, it can be categorised as the permanent establishment. With the firmness of the Permanent Establishment definition, it will undoubtedly force digital companies to comply with their taxation rights and obligations in Indonesia.

\section{Conclusion}

Tax experts agree that digital business models' development is growing so rapidly that old regulations are irrelevant. So, the Government must immediately revise the tax regulations to suit current needs. The Government is expected to be able to provide solutions regarding the definition of a permanent establishment, appoint a party to be a tax collector or withholder, the obligation to have a Taxpayer Identification Number, 
organize the rights and obligations of Taxable Entrepreneurs, and solve the problem of more transparent and fair supervision.

The focus of technological innovation in the taxation sector is considered capable of reducing administrative costs from the tax authority's perspective. The Government's concrete steps by adopting a tax administration system called the "Core Tax System" can effectively respond to current tax challenges. This innovation must be supported by human resources' quality who have the best competence in taxation and technology (called Taxologist). Before a global consensus is agreed upon in 2020, governments need to immediately secure a potential Value-Added Tax (VAT) on electronic commerce, which is easier to apply than income tax.

\section{References}

Agrawal, D. R., \& Fox, W. F. (2017). Taxes in an e-commerce generation. International Tax and Public Finance, 24(5), 903-926. doi: https://doi.org/10.1007/s10797-0169422-3

Bird, R. (2003). Taxing electronic commerce: A revolution in the making. Commentary-CD Howe Institute, (186/187), 1. Retrieved from

https://www.cdhowe.org/sites/defau lt/files/attachments/research papers /mixed//commentary_187.pdf

Cockfield, A. J. (2001). Designing tax policy for the digital biosphere: How the internet is changing tax laws. Conn. L. Rev., 34, 333. Retrieved from https://www.researchgate.net/public ation/228132820 Designing Tax P olicy_for_the_Digital_Biosphere_H ow the Internet is Changing Tax Laws
Downer, P. (2001). Taxation of electronic commerce: An examination of Canadian government tax policies and directives: Application of Adam Smith's canons of taxation. Journal of Financial Management \& Analysis, 14(1), 52. Retrieved from

https://search.proquest.com/openvie w/495728728a2ec017ebad7f7b27fb $3 \mathrm{db} 0 / 1$ ?pqorigsite $=$ gscholar $\& c b l=34285$

Hanefah, H. M. M., Hassan, H., \& Othman, Z. (2008). E-commerce Implications Potential Problems and Challenges in Malaysia. International Business Research, 1(1), 43-57. doi: https://doi.org/10.5539/ibr.v1n1p43

Horn, S. P. (2003). Taxation of ecommerce. Journal of American Academy of Business, Cambridge, 2(2), 329-329.

Jones, R., \& Basu, S. (2002). Taxation of Electronic Commerce: A Developing Problem. International Review of Law, Computers \& Technology, 16(1), 35-51. doi: https://doi.org/10.1080/1360086022 $\underline{0136093}$

Laudon, K. C., \& Traver, C. G. (2017). E-commerce: Business, technology, society. Global edition. Harlow, Essex: Pearson.

Mann, C. L., Eckert, S. E., \& Knight, S. C. (2000). Global electronic commerce: A policy primer. Peterson Institute.

Medina, L., \& Schneider, F. (2018). Shadow economies around the world: what did we learn over the last 20 years?. IMF Working Paper No. 18/17. Retrieved from https://ssrn.com/abstract=3124402

OECD. (2013). Addressing Base Erosion and Profit Shifting. Paris: OECD Publishing. 
https://doi.org/10.1787/9789264192 744-en.

Oguttu, A. W., \& Tladi, S. (2009). The challenges e-commerce poses to the determination of a taxable presence: The permanent establishment concept analyzed from a South African perspective. J. Int'l Com. L. \& Tech., 4, 213. Retrieved from https://www.researchgate.net/public ation/26628797_The_Challenges_E

Commerce_Poses_to the_Determin ation_of_a_Taxable_Presence The

Permanent Establishment Concep t_Analyzed_from_a_South_African Perspective

Omar, A., Bhutta, M. K. S., \& Sanchez, T. (2009). The impact of e-taxation policy on state and local government revenue. Electronic Government, an International Journal, 6(4), 378-390. doi: https://doi.org/10.1504/EG.2009.02 7784.

Othman, Z., \& Hanefah, M. M. (2006). Taxation, e-commerce and determination of permanent establishment. Management \& Accounting Review (MAR), 5(2), 111.

doi: http://dx.doi.org/10.24191/mar.v5i2 .306

Sekaran, U., \& Bougie, R. (2016). Research methods for business: A skill building approach. John Wiley \& Sons.
Setiawan, S. (2018). E-commerce Taxation and Fiscal Policy Perspective: The Case of Indonesia. International Journal of Research in Business and Social Science (2147-4478), 7(3), 1-9. doi: https://doi.org/10.20525/ijrbs.v7i3.9 $\underline{00}$

Smith, A. (2010). The Wealth of Nations: An inquiry into the nature and causes of the Wealth of Nations. Harriman House Limited.

Smith, G. J. (Ed.). (2007). Internet law and regulation. Sweet \& Maxwell.

Weber, D. M., \& van Weeghel, S. (Eds.). (2011). The 2010 OECD Updates: Model Tax Convention \& Transfer Pricing Guidelines: a Critical Review (Vol. 38). Alphen aan den Rijn: Kluwer Law International.

Zulma, G. W. M. (2020). Pengaruh Pengetahuan Wajib Pajak, Administrasi Pajak, Tarif Pajak dan Sanksi Perpajakan terhadap Kepatuhan Pajak Pada Pelaku Usaha UMKM di Indonesia. Ekonomis: Journal of Economics and Business, 4(2), 288-294. doi: http://dx.doi.org/10.33087/ekonomi s.v4i2.170

Zulma, G. W. M., Lutfi, L., \& Gowon, M. (2019). Era Baru: Persepsi Mendasar Wajib Pajak terhadap Tingkat Kepatuhan Pajak. Ekonomis: Journal of Economics and Business, 3(2), 113-122. doi: http://dx.doi.org/10.33087/ekonomi s.v3i2.70 
Table 1. Observation Sample

\begin{tabular}{|c|c|c|}
\hline No. & Status & Total \\
\hline 1 & Consultant & 3 \\
\hline 2 & Tax Experts & 2 \\
\hline 3 & Academics & 4 \\
\hline 4 & Manager/Heads of Corporate Tax & 2 \\
\hline 5 & E-Commerce Experts & 2 \\
\hline 6 & Tax Regulator & 2 \\
\hline Tota & & 15 \\
\hline
\end{tabular}

Source: Data Processed in 2019

Table 2. Issues Related to the Application of E-Commerce Tax in Indonesia

\begin{tabular}{|c|c|c|c|c|c|c|c|c|c|c|}
\hline \multirow[b]{2}{*}{ Problems } & \multicolumn{2}{|c|}{$\begin{array}{c}\text { Strongly } \\
\text { Agree }\end{array}$} & \multicolumn{2}{|c|}{ Agree } & \multicolumn{2}{|c|}{$\begin{array}{l}\text { Strongly } \\
\text { Disagree }\end{array}$} & \multicolumn{2}{|c|}{ Disagree } & \multicolumn{2}{|c|}{ Neutral } \\
\hline & $\%$ & $\mathbf{N}$ & $\%$ & $\mathbf{N}$ & $\%$ & $\mathbf{N}$ & $\%$ & $\mathbf{N}$ & $\%$ & $\mathbf{N}$ \\
\hline $\begin{array}{l}\text { The taxation rules } \\
\text { must be immediately } \\
\text { revised to provide } \\
\text { certainty to business } \\
\text { people regarding tax } \\
\text { obligations. }\end{array}$ & 66.7 & 10 & 33.3 & 5 & - & - & - & - & - & - \\
\hline $\begin{array}{l}\text { Digitalisation } \\
\text { changes business } \\
\text { behavior and impacts } \\
\text { different tax rules in } \\
\text { each country. }\end{array}$ & 53.3 & 8 & 46.7 & 7 & - & - & - & - & - & - \\
\hline $\begin{array}{l}\text { Indonesia should } \\
\text { make specific } \\
\text { provisions on e- } \\
\text { commerce rather than } \\
\text { changing the general } \\
\text { tax rules. }\end{array}$ & 53.3 & 8 & - & - & - & - & 26.7 & 4 & 20.0 & 3 \\
\hline $\begin{array}{l}\text { The current taxation } \\
\text { system does not } \\
\text { guarantee fair tax } \\
\text { payments to digital } \\
\text { businesses, especially } \\
\text { across countries. }\end{array}$ & 66.7 & 10 & 33.3 & 5 & - & - & - & - & - & - \\
\hline $\begin{array}{l}\text { E-commerce has the } \\
\text { potential to create a } \\
\text { greater risk of tax } \\
\text { avoidance, especially } \\
\text { for cross-border } \\
\text { business transactions. }\end{array}$ & 33.3 & 5 & 66.7 & 10 & - & - & - & - & - & - \\
\hline
\end{tabular}




\begin{tabular}{|c|c|c|c|c|c|c|c|c|c|c|}
\hline \multirow[b]{2}{*}{ Problems } & \multicolumn{2}{|c|}{$\begin{array}{l}\text { Strongly } \\
\text { Agree }\end{array}$} & \multicolumn{2}{|c|}{ Agree } & \multicolumn{2}{|c|}{$\begin{array}{l}\text { Strongly } \\
\text { Disagree }\end{array}$} & \multicolumn{2}{|c|}{ Disagree } & \multicolumn{2}{|c|}{ Neutral } \\
\hline & $\%$ & $\mathbf{N}$ & $\%$ & $\mathbf{N}$ & $\%$ & $\mathbf{N}$ & $\%$ & $\mathbf{N}$ & $\%$ & $\mathbf{N}$ \\
\hline $\begin{array}{l}\text { Resolving the } \\
\text { polemic of } \\
\text { uncertainty regarding } \\
\text { e-commerce tax } \\
\text { regulations needs to } \\
\text { be supported by } \\
\text { changes } \\
\text { internationally. }\end{array}$ & 73.3 & 11 & 26.7 & 4 & - & - & - & - & - & - \\
\hline $\begin{array}{l}\text { Indonesia has } \\
\text { difficulty } \\
\text { implementing e- } \\
\text { commerce taxes due } \\
\text { to technological } \\
\text { limitations and the } \\
\text { quality of its human } \\
\text { resources. }\end{array}$ & 66.7 & 10 & 13.3 & 2 & - & - & 6.7 & 1 & 6.7 & 1 \\
\hline $\begin{array}{l}\text { The existence of e- } \\
\text { commerce tax } \\
\text { regulations can } \\
\text { provide time certainty } \\
\text { and transparency in } \\
\text { tax administration to } \\
\text { affect the increase in } \\
\text { tax compliance. }\end{array}$ & 53.3 & 8 & 46.7 & 7 & - & - & - & - & - & - \\
\hline $\begin{array}{l}\text { Implementation of } \\
\text { AEoI (Automatic } \\
\text { Exchange of } \\
\text { Information) can } \\
\text { improve taxpayer } \\
\text { compliance in } \\
\text { reporting tax returns. }\end{array}$ & 53.3 & 8 & 46.7 & 7 & - & - & - & - & - & - \\
\hline $\begin{array}{l}\text { The Government } \\
\text { needs to regulate } \\
\text { more clearly the } \\
\text { determination of the } \\
\text { Permanent } \\
\text { Establishment (PE) } \\
\text { considering that the } \\
\text { business model of e- } \\
\text { commerce companies } \\
\text { does not use physical } \\
\text { presence to keep } \\
\text { attracting profits from } \\
\text { a country. }\end{array}$ & 66.7 & 10 & 33.3 & 5 & - & - & - & - & - & - \\
\hline
\end{tabular}

Source: Data Processed in 2019 